\title{
Lysmata rafa, a new species of peppermint shrimp (Crustacea, Caridea, Hippolytidae) from the subtropical western Atlantic
}

\author{
Andrew L. Rhyne $\cdot$ Arthur Anker
}

Received: 9 May 2007 / Revised: 25 July 2007 / Accepted: 25 July 2007 / Published online: 16 November 2007

(C) Springer-Verlag and AWI 2007

\begin{abstract}
Lysmata rafa n. sp. is described from freshly collected specimens from the Keys West Lakes, Florida Keys, and from a museum specimen collected at Bear Cut, Biscayne Bay, Florida. The new species is morphologically most similar to the western Atlantic Lysmata rathbunae Chace, 1970 and the eastern Pacific Lysmata gracilirostris Wicksten, 2000, but can be distinguished from them by the number of carpal segments in the second pereiopod; the length and dentition of the rostrum; the shape and number of spines on the dactylus of the third to fifth pereiopods; and the absence of a tooth on the pterygostomial margin of the carapace. Despite being a shallow-water species, L. rafa n. sp. has extremely elongate walking legs and third maxilliped that are more typical to deep-water or cave dwelling carideans.
\end{abstract}

Keywords Lysmata Peppermint shrimp · Hippolytidae . Caridea $\cdot$ New species $\cdot$ Western Atlantic $\cdot$ Florida .

Color pattern

Communicated by Peter Funch.

A. L. Rhyne

Department of Biological Sciences,

Florida Institute of Technology,

150 West University Blvd,

Melbourne, FL 32901, USA

A. Anker

Instituto Smithsonian de Investigaciones Tropicales (STRI),

Apartado 0843-03092, Balboa, Ancón, Panamá,

República de Panamá

A. L. Rhyne ( $\square)$

Indian River Research and Education Center,

University of Florida-IFAS, 2199 South Rock Road,

Fort Pierce, FL 34945, USA

e-mail: arhyne@ufl.edu

\section{Introduction}

The genus Lysmata Risso, 1816 (Hippolytidae sensu lato, Lysmatidae sensu Christoffersen 1987), which includes conspicuous peppermint and cleaner shrimps, as well as a number of less colorful species, is well represented in the western Atlantic, with ten described and several undescribed species (Chace 1970, 1972; Rhyne and Lin 2006). Most of them occur in shallow waters, on hard and mixed bottoms, such as rocky intertidal, turtle grass beds with rocks and rubble and coral reefs. Most Lysmata species are identifiable in the field by their diagnostic color patterns (Rhyne and Lin 2006).

While diving in June 2003 around the Key West Lakes area, west of Key West, Florida (Fig. 1), the senior author (AR) was able to collect three different species of Lysmata from shallow water hard bottom ledges. Two of these species were identified by color pattern as $L$. wurdemanni Gibbes, 1850 and L. boggessi Rhyne and Lin, 2006. However, the third species had a different and unique color pattern. One of the four collected specimens, in poor condition, was preserved in the field; the remaining specimens were transported to the laboratory for behavioral observations. In the laboratory, another specimen was preserved to ensure a fully intact specimen was available for morphological study. The remaining two individuals were maintained alive in a 20-1 tank at the Vero Beach Marine Laboratory (Florida Institute of Technology, USA). They were observed for sexual development over the next 4 months. In August 2005 and May 2006, additional specimens of this species were collected in the same area. The May 2006 collection yielded a pair of shrimp that were reproductively mature.

A closer inspection of morphology of the unidentified specimens from Key West Lakes revealed that they all 


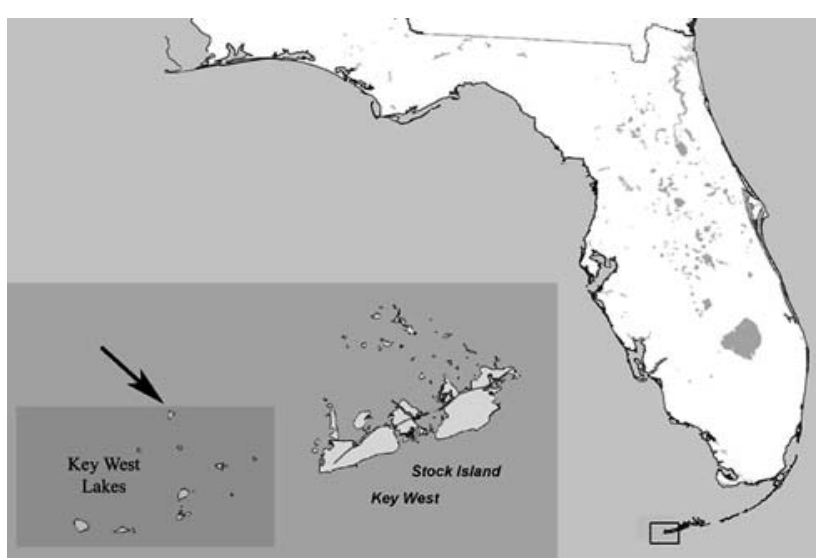

Fig. 1 Map of Florida, USA; insert shows Key West and Key West Lake areas, arrow indicating collection area

represented an undescribed species. This species is herewith described as new; its morphological features and the diagnostic color pattern are illustrated.

\section{Materials and methods}

The description of the new species is based on freshly collected specimens, four males and one euhermaphrodite from Key West Lakes, and one preserved specimen from Bear Cut, Florida, from the collections of the National Museum of Natural History, Smithsonian Institution, Washington, DC, USA (USNM). The type material is deposited in the USNM and the Muséum national d'Histoire naturelle, Paris, France (MNHN). Progeny from a pair collected in the wild were reared and their offspring were grown in the laboratory for six months post settlement. Specimens of Lysmata species used for comparison with the new species remain deposited in the collections of the Florida Fish and Wildlife Research Institute, St Petersburg, FL, USA (FSBC-I) and USNM. The carapace length (CL, in $\mathrm{mm}$ ) was measured along the mediodorsal line from the postorbital margin to the posterior margin of the carapace.

Systematic account

Family Hippolytidae Dana, 1852

(Lysmatidae Dana, 1852 in Christoffersen 1987)

Genus Lysmata Risso, 1816

Lysmata rafa n. sp.

Figs. $2-4$

Lysmata rathbunae "variety" (Chace 1970, p. 59), in part. (Specimens from shallow water, not from tube sponges, with more than 40 articles on the carpus of the second pereiopod.) Lysmata rathbunae "variety" (Chace 1970, p. 59), in part. (Specimens from shallow water, not from tube sponges, with more than 40 segments on the carpus of the second pereiopod.)
Type material

Holotype: euhermaphrodite, CL 10 mm, USNM 1100306 Florida, Key West Lakes, West of Key West, under ledge, depth about 1 m, coll. A.L. Rhyne, 12 May 2006 (collected as pair together with paratype, USNM 1100307). Paratypes: one male, CL $8 \mathrm{~mm}$, USNM 1100307, same collection data as for holotype; one male, CL $6 \mathrm{~mm}$, MNHN-Na 16398, Florida, Key West Lakes, West of Key West, under ledge, depth about $1 \mathrm{~m}$, coll. A.L. Rhyne, 8 June 2003; one male, CL 4 mm, MNHN-Na 16399, same collection data as for previous specimen (specimen in poor condition); one male, CL 4 mm, MNHN-Na 16400, Florida, Key West Lakes, West of Key West, under ledge, depth about $1 \mathrm{~m}$, coll. A.L. Rhyne, 10 August 2005.

\section{Non-type material}

One ovigerous euhermaphrodite, CL $9.5 \mathrm{~mm}$, USNM 136402, Florida, Bear Cut, North End of Biscayne Key, under rock, coll. R.B. Manning, 12 March 1961 (identified as $L$. rathbunae variety by F.A. Chace).

\section{Description}

Rostrum elongate, slender, curved upwards, about 1.2 times as long as carapace, usually reaching or surpassing end of antennular peduncle (Fig. 2a-c); dorsal margin with at least seven teeth, most posterior tooth situated on dorsal carina of carapace far beyond postorbital margin, second tooth above or slightly posterior to postorbital margin, remaining teeth well spaced, anterior to postorbital margin; ventral margin usually with seven to nine teeth, closely spaced, most-proximal ventral tooth situated at level ranging from mid-length of first segment to proximal end of second segment of antennular peduncle; distal-most ventral and dorsal teeth somewhat isolated from preceding teeth; rostrum tip usually tridentate (Fig. 2b, c, o). Carapace smooth, 1.7 times as long as high, posteroventral margin rounded; pterygostomial angle without tooth. Eyes relatively large (Fig. 2b, c, o). Antennal tooth very long, reaching to or close to posterior margin of cornea. Antennular peduncle not or only slightly overreaching scaphocerite; first segment with three spines on distodorsal margin; stylocerite not reaching to anterior margin of eye (Fig. 2d); ventromesial carina with small anteriorly directed tooth (Fig. 2d); second segment more than twice as long as wide, about twice as long as high, with one or two spines on dorsal margin (Fig. 2b, d); third segment with two spines on dorsal margin; lateral antennular flagellum long, over twice body length, with aesthetascs extending from seventh to thirtieth segment in larger males or euhermaphrodites, secondary ramus reduced to rudiment (Fig. 2e). Scaphocerite five to six times 


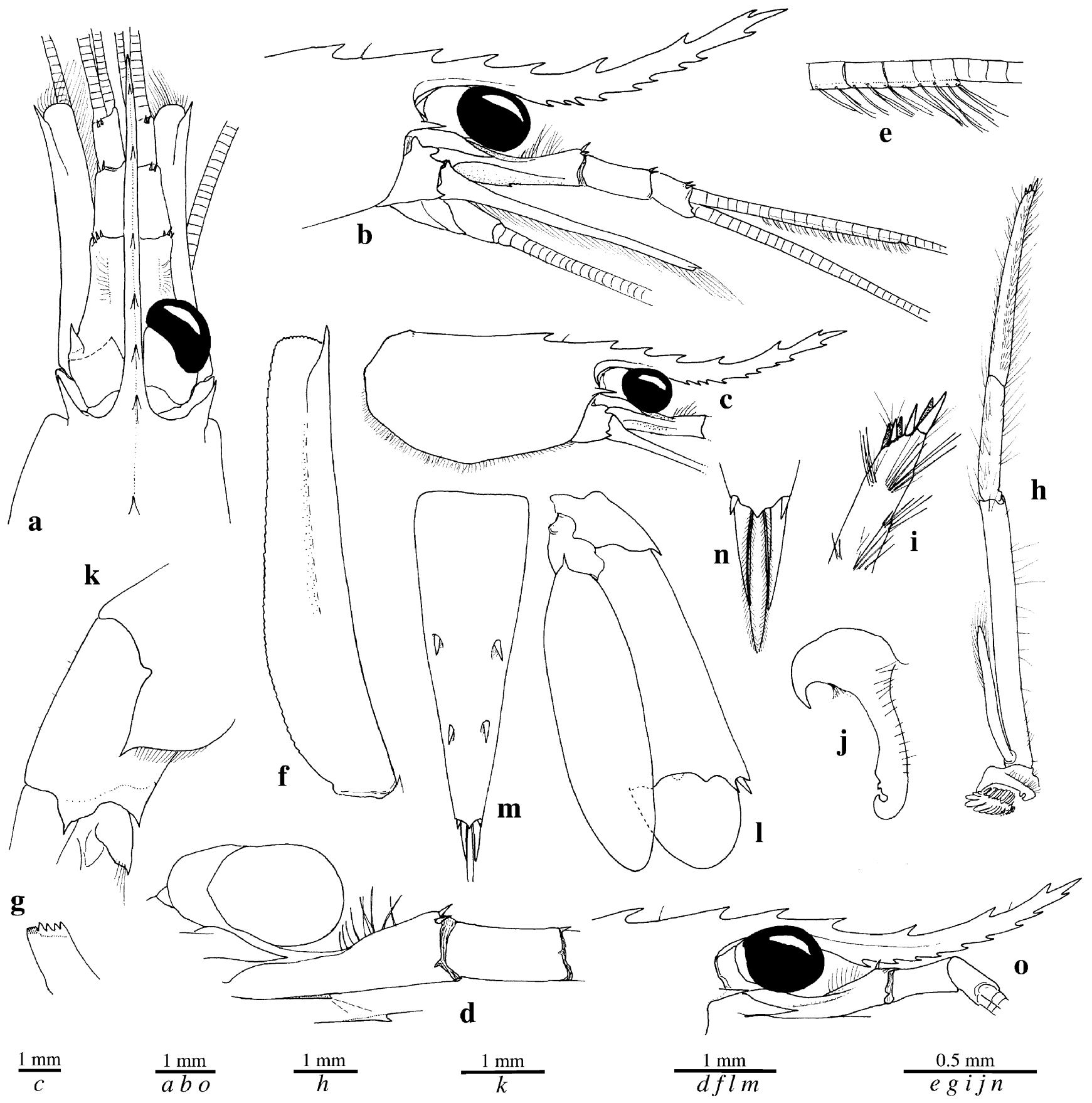

Fig. 2 Lysmata rafa n. sp., male paratype MNHN-Na 19399. a Anterior region, dorsal view. b Same, lateral view. c Carapace, lateral view. d First segment of antennular peduncle, with detail of tooth on ventromesial carina. e Antennular flagellum with rudimentary secondary ramus.

f Right antennal scale. g Mandible. $\mathbf{h}$ Right third maxilliped. i Same, tip of ultimate segment. j Same, epipod. k Fifth and sixth abdominal somites, lateral view. I Right uropod, dorsal view. m Telson, dorsal view. $\mathbf{n}$ Same, posterior margin. Scale bars as indicated in figure

as long as wide, with slightly concave lateral margin; distolateral tooth greatly overreaching blade (Fig. 2f).

Abdomen more than twice carapace length. Pleura of first three abdominal somites with rounded margin; pleuron of fourth somite lacking sharp posterolateral tooth; pleuron of fifth somite with sharp posterolateral tooth; sixth somite about 1.6 times as long as fifth, with acute posteroventral tooth and acute posterior tooth flanking base of telson (Fig. 2k). Telson

about 1.5 times as long as sixth abdominal somite, tapering posteriorly; dorsal surface with two pairs of spines (Fig. 2m); posterior margin medially acute, with pair of long slender spines each flanked by much shorter spine (Fig. 2m, n); two long plumose setae present between long spines (Fig. 2n).

Mouthparts typical for genus; mandible as illustrated (Fig. 2g). Third maxilliped overreaching scaphocerite, lateral plate posteriorly curved, acute (Fig. 2j); exopod about $2 / 3$ 
length of antepenultimate segment; ultimate segment twice as long as penultimate segment, tip with four spines (Fig. 2h, i).

First pereiopod with simple chela (Fig. 3a, b), reaching nearly to end of scaphocerite when fully extended; ischium with row of spinules on ventral margin (Fig. 3c); merus subequal to carpus; palm about four times as long as dactylus, six times as long as high (Fig. 3b). Second pereiopods slender, subequal in length, ending in small simple chelae (Fig. 3d); merus with 25 segments; carpus twice as long as merus, reaching to second segment of antennular peduncle, with 40-43 segments (Fig. 3d). Third to fifth pereiopods similar, decreasing in length from third to fifth; proximal end of carpus of third pereiopod reaching just beyond second segment of antennular peduncle; merus with five spines, three times as long as ischium, twice as long as carpus; propodus 1.3 times length of merus; dactylus 1/7 length of propodus (Fig. 3e); dactyli biunguiculate, usually armed with four-five spines, dorsal unguis longer than ventral, flexor margin with two-three spinules, decreasing in size from proximal to distal, most-proximal spinule minute (Fig. 3f). Fourth pereiopod similar to third, carpus reaching to third segment of antennular peduncle. Fifth pereiopod with merus less than 1.5 times carpus length, reaching to second segment of antennular peduncle, bearing five spines; propodus with three-four rows of dense setae on distal end of flexor margin (Fig. 3g). Uropod without specific features (Fig. 2l).

\section{Color in life}

Body translucent with red longitudinal and diagonal stripes (Fig. 4a, b); carapace with inverted U-shaped band, abdominal pleura with narrow longitudinal stripes (dorsal view showing three, with one running along entire length of abdomen), third pleuron with transverse band in conspicuous Ushaped pattern, connecting with two lateral longitudinal stripes (Fig. 4b); telson and uropods with intense red longitudinal bands. Color of embryos and eggs reddish pink.

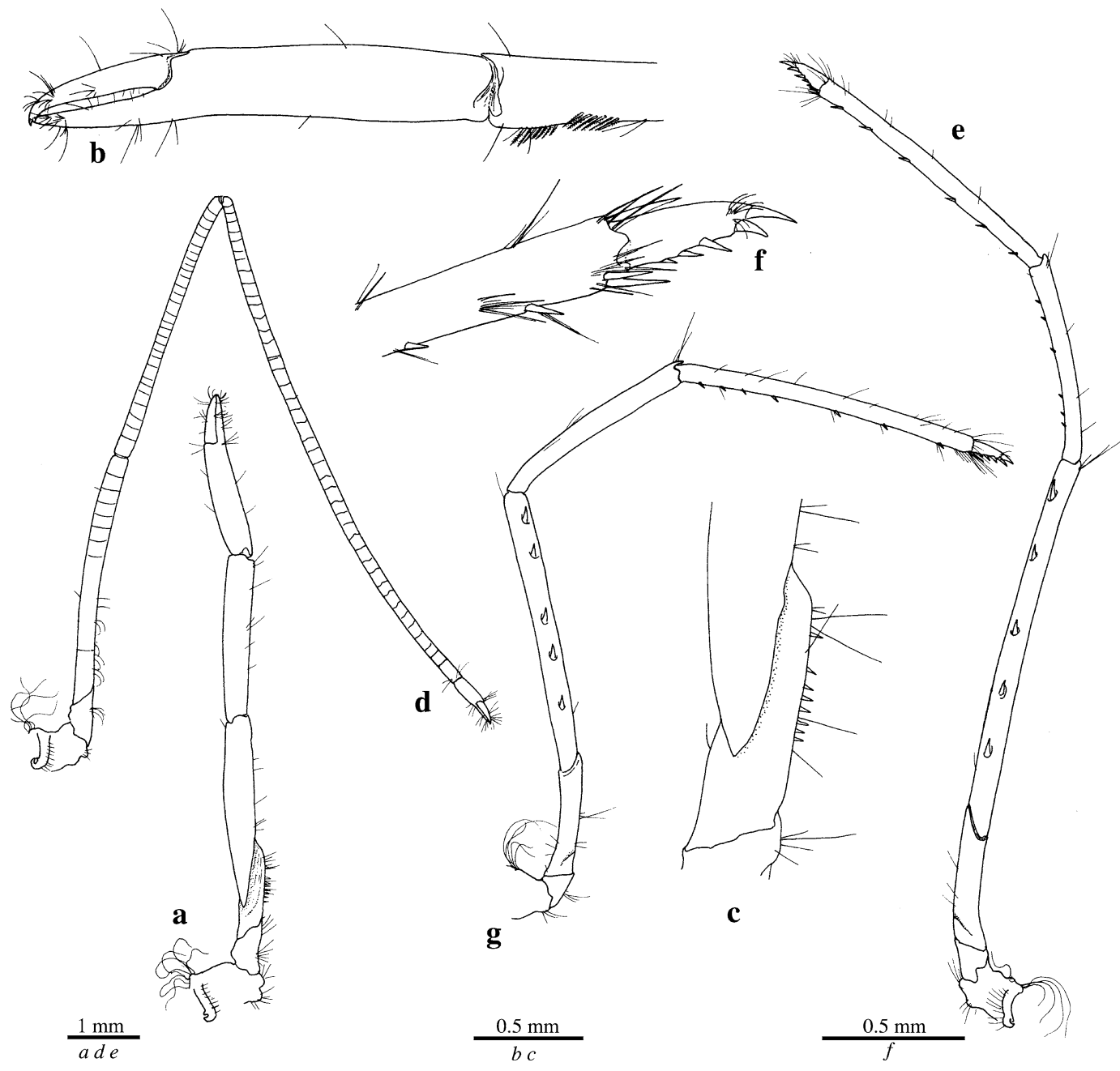

Fig. 3 Lysmata rafa n. sp., male paratype MNHN-Na 19399. a Right first pereiopod, lateral view. b Same, detail of chela. c Same, detail of ischium. d Right second pereiopod, lateral view. e Right third pereiopod, lateral view. f Same, detail of dactylus. $\mathbf{g}$ Right fifth pereiopod, lateral view. Scale bars as indicated in figure 

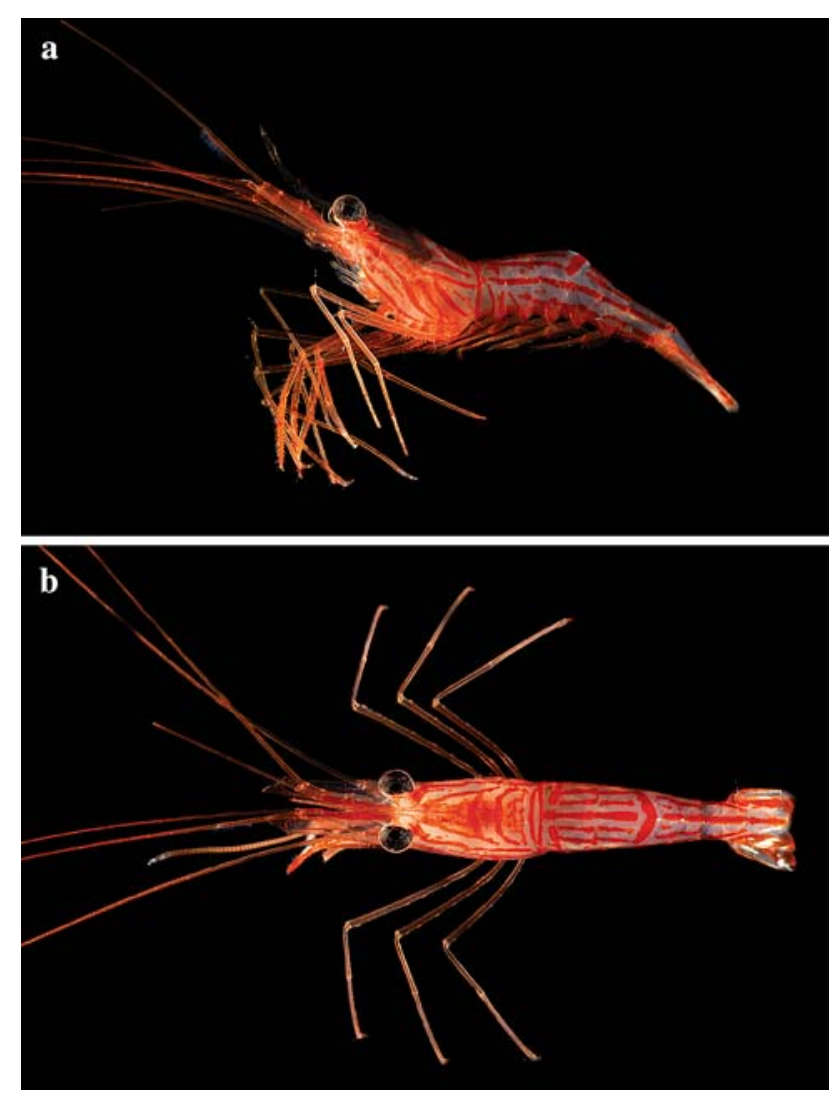

Fig. 4 Live color pattern of Lysmata rafa n. sp. a Lateral view. b Dorsal view

Size

The largest male specimen attains $8 \mathrm{~mm} \mathrm{CL}$; the euhermaphrodites are 9.5-10 $\mathrm{mm}$ CL.

\section{Etymology}

The new species is named after our colleague, Dr. Rafael Lemaitre, curator of the Crustacea at the National Museum of Natural History, Smithsonian Institution, Washington, DC, for his numerous contributions to the taxonomy of decapod crustaceans, and also for his invaluable assistance to us during our stays at the USNM. The specific name rafa, short for Rafael, is used as a noun in opposition.

\section{Type locality}

Key West Lakes, North of Cottrell Key, Florida Keys, USA.

\section{Distribution}

Presently known only from southern Florida: Biscayne Bay and Key West Lakes, Florida, USA (Fig. 1).

\section{Biology}

Presently $L$. rafa n. sp. is known only from the shallow rocky subtidal of the southern Florida Keys. Most specimens were found inside small ledges, in water not deeper than $1 \mathrm{~m}$. The shrimps live in small groups or individually. The presence of small males suggests recruitment into the type locality, whereas larger males and euhermaphrodite pairs suggests "retention" in the shallow water system. The presence of adults and juveniles suggests $L$. rafa n. sp. is a true shallow water species.

Lysmata rafa n. sp. occurs sympatrically with several other species of Lysmata, with populations of some (e.g., $L$. wurdemanni and L. boggessi) numbered by thousands in the summer of 2003, but notably lower after the hurricanes of 2004 and 2005 (A. Rhyne, pers. obs.). In the Key West Lakes, L. rafa n. sp. has never been collected from the same ledges as L. wurdemanni and L. boggessi, which appear to live in close quarters along the ledge system, suggesting that it might occupy a slightly different ecological niche.

Based on our laboratory observations, L. rafa n. sp. does not display a rapid sex change as do many other Lysmata species (see for example Zhang et al. 1998; Lin and Zhang 2001), in which under laboratory conditions sex change usually occurs within 30-70 days after metamorphosis to post-larvae. The two specimens collected in 2003 appeared to be well beyond post-larval stage (when they were collected); they were held for approximately 4 months without changing sex and were finally lost due to a bacterial infection of the gills (Vibrio sp.).

A gravid euhermaphrodite kept in the laboratory released larvae that were similar to those of other Lysmata species characterized by the absence of an accessory branch on the lateral antennular flagellum (species of the L. wurdemanni complex). Larvae hatch as zoea with a size of $\sim 3.4 \mathrm{~mm}$ total length; after 11 zoeal stages, approximately 26 days, undergo metamorphosis, becoming juvenile shrimps with a total length of about $15 \mathrm{~mm}$. More recently, individuals from a wild-spawned clutch reared in captivity for over 6 months began to change sex to euhermaphrodite phase. Furthermore, L. rafa, n. sp. seems to be under a stronger social control than for example L. ankeri Rhyne and Lin, 2006 (Lin and Zhang 2001) or L. wurdemanni (Baeza and Bauer 2004). However, more data is required before any conclusions can be drawn on the exact reproductive strategy of this species.

\section{Remarks}

Chace's (1970) description of L. rathbunae Chace, 1970 included several specimens that had, as Chace noted, "disconcerting abnormalities". These specimens were separated from the typical specimens of $L$. rathbunae under the name 
"L. rathbunae variety" (Chace 1970). Lysmata pederseni, a species with a long thick rostrum commonly found in tube sponges, corresponds to Chace's sponge dwelling "variety" of $L$. rathbunae. Lysmata rafa $\mathrm{n}$. sp. is the second species that Chace (1970) grouped together under "L. rathbunae variety". As pointed out by Rhyne and Lin (2006), the true L. rathbunae is a deep-water species found below $30 \mathrm{~m}$. Therefore, all specimens collected in shallower water (less than $15 \mathrm{~m}$ ) and identified as L. rathbunae should be carefully re-examined. One of us (AR) investigated shallow water specimens identified as $L$. rathbunae deposited in the USNM and found at least one specimen (USNM 136402) listed by Chace (1970) under L. rathbunae that actually corresponds to L. rafa n. sp.

The new species appears to be morphologically closest to L. rathbunae from the western Atlantic (Chace 1970) and L. gracilirostris Wicksten, 2000 from the eastern Pacific (Wicksten 2000), especially in having a long, slender rostrum and elongate third maxilliped and walking legs. However, L. rafa n. sp. can be distinguished from L. rathbunae by the number of carpal segments in the second pereiopod (40-43 in L. rafa n. sp. vs. 30-35 in L. rathbunae); the dentition, length and shape of the rostrum (in L. rafa n. sp.: seven or more dorsal, seven to nine ventral, extending beyond antennular peduncle, curved dorsally; in L. rathbunae: five to six dorsal, three to five ventral, extending not well beyond antennual peduncle, mostly straight or slightly curved ventrally); and the relative length of the antennular peduncle to the scaphocerite (nearly equal in L. rafa n. sp. vs. distinctly shorter in L. rathbunae). Lysmata rafa n. sp. can be easily distinguished from L. gracilirostris by the position of the second and third dorsal teeth on the rostrum (second just posterior to or at level of orbit, third well anterior to orbit in L. rafa n. sp. vs. second well posterior to orbit, third at or near level of orbit in L. gracilirostris); the number of carpal segments in the second pereiopod (40-43 in L. rafa n. sp. vs. 28-30 in L. gracilirostris); the longer spinules on the dactylus of the third to fifth pereiopods; and the absence of a pterygostomial tooth (present in L. gracilirostris).
Within Lysmata, an extreme elongation of appendages typically occurs in deep water species (found below $50 \mathrm{~m}$ ). However, L. rafa n. sp. is a shallow water species with slender elongate walking legs and third maxilliped, suggesting that this feature is not always an adaptation to deep-water environments.

Acknowledgments The authors wish to thank the staff of the USNM Department of Invertebrate Zoology, Karen Reed and Rafael Lemaitre, for their continuous assistance and access to the USNM collections; Junda Lin and Dong Zhang (FIT) for technical assistance; an anonymous reviewer for valuable comments; Eric Pedersen for providing support in the field and pointing out to the collection site of the new species; Matt Wittenrich for kindly providing color photographs; and A. Richard Palmer (University of Alberta, Edmonton, Canada) for supporting one of us (AA) with a fellowship from a NSERC operating grant (A7245).

\section{References}

Baeza JA, Bauer RT (2004) Experimental test of socially mediated sex change in a protandric simultaneous hermaphrodite, the marine shrimp Lysmata wurdemanni (Caridea: Hippolytidae). Behav Ecol Sociobiol 55:544-550

Chace F Jr (1970) A new shrimp of the genus Lysmata (Decapoda, Hippolytidae) from the western Atlantic. Crustaceana 19:59-66

Chace F Jr (1972) The shrimps of the Smithsonian-Bredin Caribbean expeditions with a summary of the West Indian shallow-water species (Crustacea: Decapoda: Natantia). Smithson Contrib Zool 98:1-179

Christoffersen ML (1987) Phylogenetic relationships of hippolytid genera, with an assignment of new families for the Crangonoidea and Alpheoidea (Crustacea, Decapoda, Caridea). Cladistics 3:348-362

Lin J, Zhang D (2001) Reproduction in a simultaneous hermaphroditic shrimp, Lysmata wurdemanni: any two will do? Mar Biol 139:919-922

Rhyne AL, Lin J (2006) A western Atlantic peppermint shrimp complex: redescription of Lysmata wurdemanni (Gibbes), description of four new species, and remarks on $L$. rathbunae Chace (Crustacea: Decapoda: Hippolytidae). Bull Mar Sci 79:165-204

Wicksten MK (2000) A new species of Lysmata (Caridea, Hippolytidae) from the eastern Pacific. Crustaceana 73:207-213

Zhang D, Lin J, Creswell LR (1998) Effects of food and temperature on survival and development in the peppermint shrimp Lysmata wurdemanni. J World Aquacult Soc 29:471-476 